Document downloaded from:

http://hdl.handle.net/10251/165396

This paper must be cited as:

Lineros-Rosa, M.; Miranda Alonso, MÁ.; Lhiaubet, VL. (2020). A Sunscreen-Based Photocage for Carbonyl Groups. Chemistry - A European Journal. 26(32):7205-7211. https://doi.org/10.1002/chem.202000123

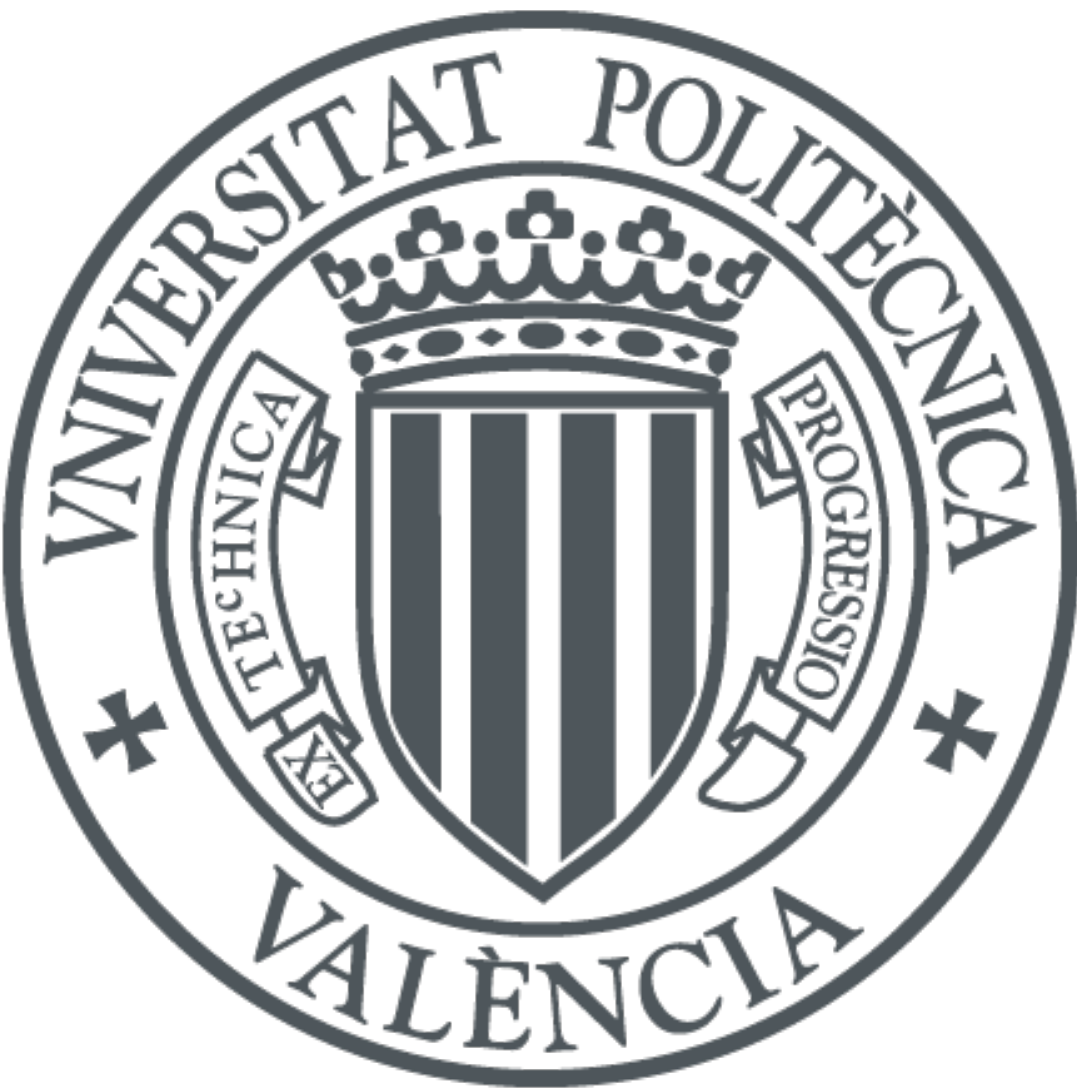

The final publication is available at

https://doi.org/10.1002/chem.202000123

Copyright John Wiley \& Sons

Additional Information

This is the peer reviewed version of the following article: M. Lineros-Rosa, M. A. Miranda, V. Lhiaubet-Vallet, Chem. Eur. J. 2020, 26, 7205, which has been published in final form at https://doi.org/10.1002/chem.202000123. This article may be used for non-commercial purposes in accordance with Wiley Terms and Conditions for Self-Archiving. 


\title{
A Sunscreen-based Photocage for Carbonyl Groups
}

\author{
Mauricio Lineros-Rosa, Miguel A. Miranda*, Virginie Lhiaubet-Vallet* \\ Instituto Universitario Mixto de Tecnología Química (UPV-CSIC), Universitat Politècnica de València, \\ Consejo Superior de Investigaciones Científicas \\ Avda de los Naranjos, s/n, 46022 Valencia, Spain \\ E-mail:mmiranda@gim.upv.es (MAM), Ivirgini@itq.upv.es (VLV)
}

\begin{abstract}
Photoremovable protecting groups (PPG) have been exploited in a large set of chemical and biological applications, due to their ability to provide spatial and temporal control over light-triggered activation. In this work, we explore the concept of a new photocage compound based on the commercial UVA/UVB filter oxybenzone (OB, 2-hydroxy-4-methoxybenzophenone) for photoprotection and controlled release of carbonyl groups. The point here is that oxybenzone not only acts as a mere PPG, but also provides, once released, UV photoprotection to the carbonyl derivative. This design points to a possible therapeutic approach to reduce the severe photoadverse effects of drugs containing a carbonyl chromophore.
\end{abstract}

\section{Introduction}

Photolabile protecting groups (PPGs) are now integral part of the organic chemist toolbox. Their removal, which generally takes place in neutral media and without the addition of any reagent, makes them appealing alternatives to the conventional methods employing basic, acidic, reductive or oxidative conditions. A salient feature relies on the accurate spatial and temporal control of the photodeprotection process that has been exploited in advantageous approaches for the release of chemicals such as acids, bases, oxidants, ions, drugs, pheromones or fragrances. ${ }^{[1-11]}$ In this context, PPGs have found a wide range of applications in organic chemistry, biochemistry, biology, polymer science, lithography, toiletry, pest-control, etc. ${ }^{[1-}$ 11]

Among the available PPGs, relatively few have found utility for caging carbonyl functional groups. ${ }^{[6-9]}$ These PPGs are applicable not only in multi-step organic synthesis, where carbonyls often require protection against nucleophiles, oxidative or reductive agents, but also for biological purposes to release bioactive compounds. Early w ork on carbonyl caging compounds was based on acetals from o-nitrophenylethylene glycol. ${ }^{[12,}$ 13] Later, a series of 1,3-dioxolane and 1,3-dioxane derivatives have been investigated to optimize the photouncaging process..$^{[8,14-20]}$

With this background, our interest $w$ as to explore the concept of sunscreen-based photocages for photoprotection and controlled release of carbonyl compounds. This is a new PPG application recently addressed by our group to release a photosensitive drug together with its UV-protector shield, which w ould make special sense for carbonyl compounds in view of their w ell-established photoreactivity. ${ }^{[34,35]}$ Until now, we have made use of the phenacyl-like structure of the avobenzone diketo tautomer to cage the carboxylic acid group of non-steroidal antiinflammatory drugs such as ketoprofen and diclofenac. ${ }^{[34,35]}$

In the present work, the commercial UVA/UVB filter oxybenzone $(\mathrm{OB})$ has been the cornerstone of our new carbonyl photocage design (Figure 1A). Actually, this solar filter plays a dual role acting not only as the photoremovable group but also providing an efficient UV shield effect to protect the carbonyl-derived drug after its photorelease. We have proven the concept studying derivative 1 as a new carbonyl photocage for the photorelease of a water soluble aromatic ketone (4-carboxybenzophenone, CBP) along with $\mathrm{OB}$ (Figure $1 \mathrm{~A}$ ).

\section{Results and Discussion}

As a first experiment, the UV-Vis absorption spectra of the carbonyl compound, 4-carboxybenzophenone (CBP), and the oxybenzone sunscreen (OB) w ere recorded in $\mathrm{H}_{2} \mathrm{O}: \mathrm{MeCN}$ (40:60, $\mathrm{v}: \mathrm{v})$ (Figure 1B). The former exhibits a maximum at $257 \mathrm{~nm}$, whereas the latter, as expected for a UVA/UVB filter, shows a broad band with maxima at ca. 287 and $325 \mathrm{~nm}$, which should provide the purported protection to CBP. This was confirmed by HPLC analysis of simulated solar light irradiations (SSL) of CBP alone and in the presence of OB (Figure S1).

Then, the photolabile compound $\mathbf{1}$ was synthesized in four steps (Scheme 1). First, the carboxylic acid of 4-carboxybenzophenone (CBP) $w$ as esterified to compound 3 , then selective reduction of the ketone was achieved by using $\mathrm{NaBH}_{4}$. The obtained alcohol reacted with oxybenzone (OB) in the presence of triphenylphosphine $\left(\mathrm{PPh}_{3}\right)$ and diisopropyl azodicarboxylate (DIAD) through a Mitsunobu reaction to yield the diaryl ether $\mathbf{5}$, which finally gave rise to 1 after basic hydrolysis. The UV-Vis absorption spectra of photocage 1 displays a long wavelength band peaking at $310 \mathrm{~nm}$ that reaches the UVA region, and making conceivable the photorelease using SSL.

The progress of steady-state photolysis of $1\left(2 \times 10^{-4} \mathrm{M}\right)$ in oxygenfree $\mathrm{MeCN}: \mathrm{H}_{2} \mathrm{O}$ (60:40, v:v) was followed by HPLC. It was observed that both $\mathrm{OB}$ and $\mathrm{CBP}$ are photoreleased together with other photoproducts (Figure $1 \mathrm{C}$ ). The peaks corresponding to $\mathbf{1}$, $\mathrm{OB}$ and $\mathrm{CBP}$ were assigned by comparison $w$ ith standards, and w ere quantified along the irradiation to obtain the kinetic curves. Moreover, peaks eluting at 2.3 and $3.4 \mathrm{~min}$ exhibit the kinetic behavior of an intermediate $w$ ith an increase of area to a maximum after $60 \mathrm{~min}$ follow ed by a decrease. 

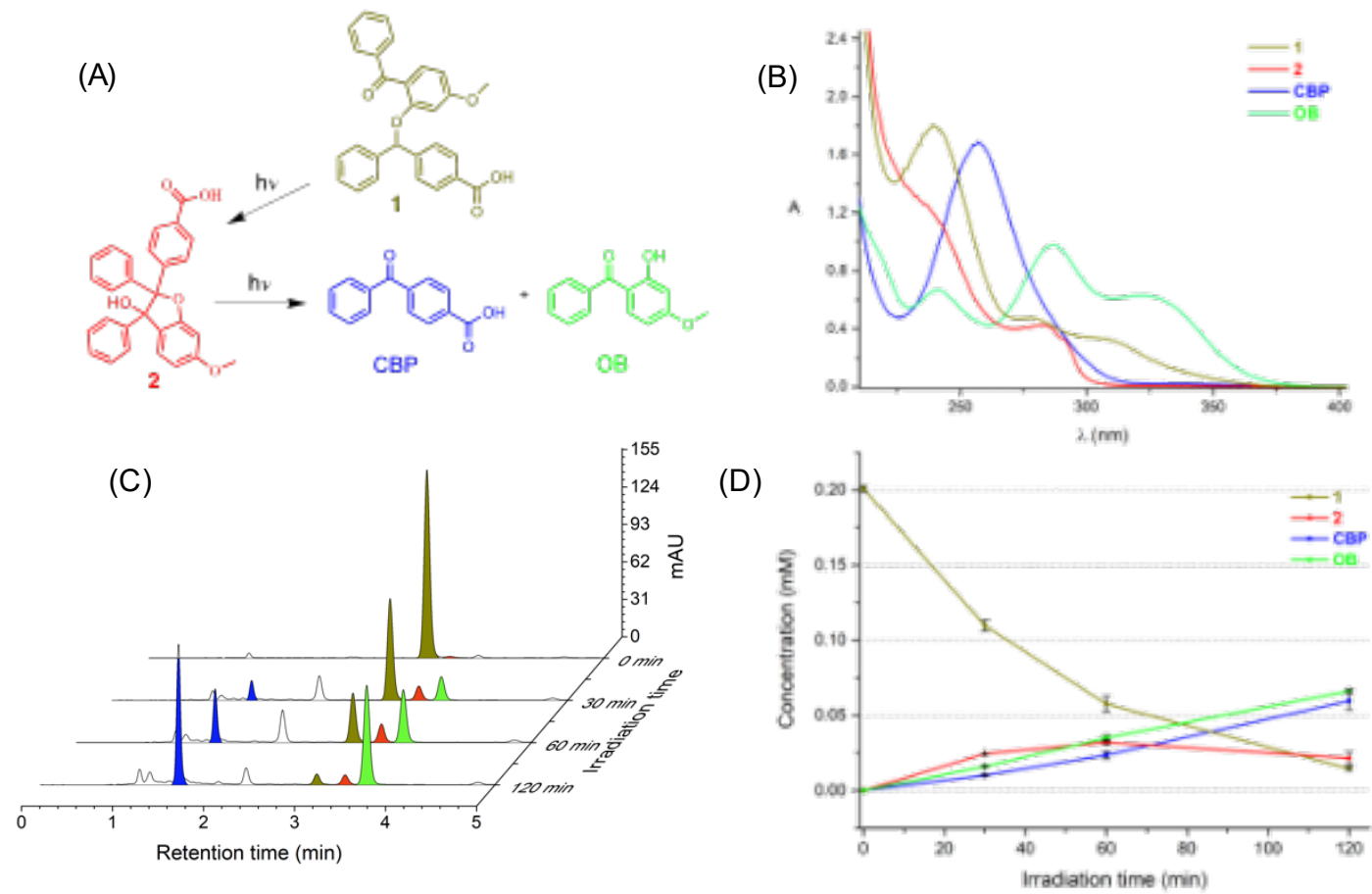

Figure 1. (A) Photorelease of $\mathrm{CBP}$ and $\mathrm{OB}$ from new carbonyl photocage 1 (B) UV-Vis absorption spectra in oxy gen-containing MeCN: $\mathrm{H}_{2} \mathrm{O}$ (60:40, v $\mathrm{v}$ ) of 1,2 $\mathrm{CBP}$ and $\mathrm{OB}$ at same concentration $\left(6.6 \times 10^{-5} \mathrm{M}\right),(\mathrm{C}) \mathrm{HPLC}$ chromatograms registered at $280 \mathrm{~nm}$ for an oxy gen-free MeCN: $\mathrm{H}_{2} \mathrm{O}(60: 40, \mathrm{v}: \mathrm{v})$ solution of $1\left(2 \times 10^{-4}\right.$ $\mathrm{M})$, upon irradiation at different times with simulated solar light, and (D) kinetic traces of 1, 2, CBP and OB.

These compounds were assigned to the diastereoisomers of cyclic intermediate 2 (see $\mathrm{SI}$ ). They are obtained from 1 by an intramolecular hydrogen abstraction and a subsequent $\mathrm{C}-\mathrm{C}$ coupling of the formed biradical (see Scheme 1 for a similar reaction of the methyl ester $\mathbf{5}$ ). Indeed, this intermediate is in turn a clear photocage for CBP, which is then released together with OB.

In order to get a deeper understanding about the photorelease process of $\mathrm{OB}$ and $\mathrm{CBP}$ from this cyclic intermediate, 2 was synthesized and used for additional steady-state photolysis experiments. In a first stage, an oxygen-containing solution of compound 2 in $\mathrm{MeCN}: \mathrm{H}_{2} \mathrm{O}$ (60:40, v:v) w as irradiated with SSL to confirm the intermediate capacity to photorelease $\mathrm{OB}$ and CBP (Figure S3D). Then, to simplify the quantitation process, experiments were performed using a low pressure $\mathrm{Hg}$ lamp with a monochromatic output at $254 \mathrm{~nm}$ under atmosphere of $\mathrm{N}_{2}$ or air. Compound $2\left(2 \times 10^{-4} \mathrm{M}\right)$ dissolved in anhydrous $\mathrm{MeCN}$ or in MeCN: $\mathrm{H}_{2} \mathrm{O}$ (60:40, v:v) was irradiated, and the reaction was follow ed by UV-Vis absorption spectrophotometry. In all cases, it w as observed an absorption increase as a function of irradiation time, and a new band peaking at ca. $325 \mathrm{~nm}$ appeared, pointing to $\mathrm{OB}$ formation. A similar behavior $w$ as observed under the different conditions (Figure S2).

Moreover, to reach a more accurate analysis of the irradiated samples, aliquots were taken at periodic intervals and analyzed by HPLC. The compound $\mathbf{2}$ was consumed during the irradiation irrespective of the employed conditions, whereas the release of CBP strongly differed depending on the presence of oxygen and/or water. As show $\mathrm{n}$ in Figure 2 for an oxygen-containing $\mathrm{MeCN}: \mathrm{H}_{2} \mathrm{O}$ solution, the peak of compound 2, eluting at $3.4 \mathrm{~min}$, decreased giving basically rise to the formation of the desired CBP (at $1.5 \mathrm{~min}$ ), together with OB (at $3.7 \mathrm{~min}$ ). The yields of the photoproducts determined after $60 \mathrm{~min}$ of irradiation are summarized in Table 1 . The results were clearly affected by the presence of $\mathrm{O}_{2}$ or $\mathrm{H}_{2} \mathrm{O}$. In oxygen-containing aqueous acetonitrile,

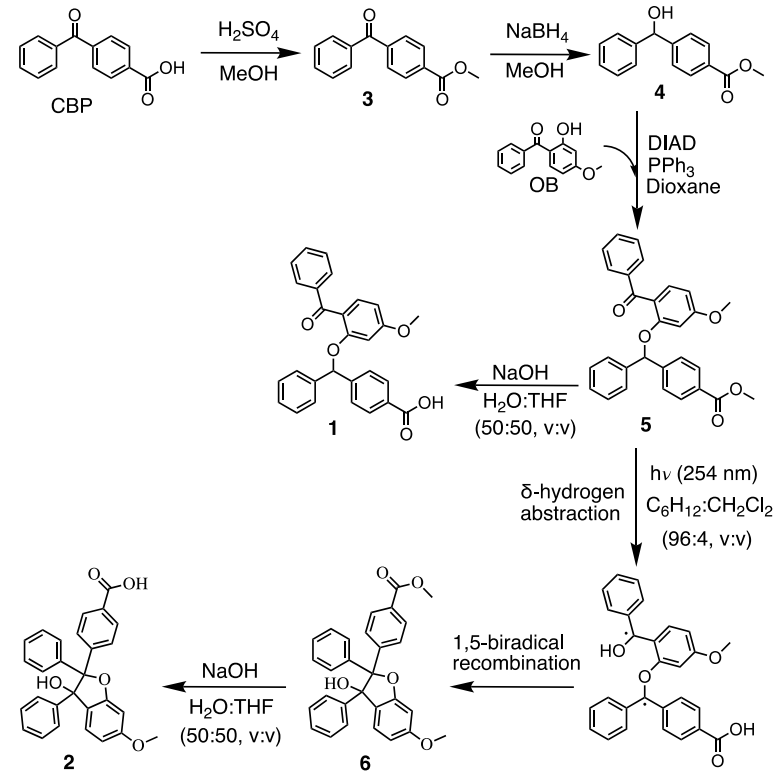

Scheme 1. Synthesis of compounds 1 and 2

the yields of $\mathrm{CBP}$ and $\mathrm{OB}$ w ere markedly higher and the formation of undesired byproducts $w$ as minimized (Figure S3).Remarkably, when oxygen and $w$ ater were present in the solution, CBP yield reached $51.7 \%$, whereas the yield of OB grew from $7.6 \%$ to $21.1 \%$. A quantum yield of ca. $0.16 \mathrm{w}$ as determined for the photoreaction by means of an established procedure using as standard the photocyclization of $\mathrm{N}$-methyldiphenylamine to $\mathrm{N}$-methylcarbazole in oxygen-containing acetonitrile (see Experimental Section). ${ }^{[36]}$ 
Table 1. Yields of compounds 2, CBP and $O B$ obtained after $60 \mathrm{~min}$ of irradiation under different conditions.

\begin{tabular}{llll}
\hline & Conversion (\%) & 4-CBP (\%) & OB (\%) \\
\hline Anhy drous $\mathrm{MeCN}, \mathrm{N}_{2}$ & $85.4 \pm 0.3$ & $9.1 \pm 1.6$ & $7.6 \pm 1.2$ \\
$\mathrm{MeCN} / \mathrm{H}_{2} \mathrm{O}, \mathrm{N}_{2}$ & $89.1 \pm 0.7$ & $6.1 \pm 0.3$ & $19.0 \pm 0.5$ \\
Anhy drous MeCN, Air & $82.4 \pm 1.8$ & $36.3 \pm 1.4$ & $20.6 \pm 0.5$ \\
$\mathrm{MeCN} / \mathrm{H}_{2} \mathrm{O}$, Air & $87.8 \pm 0.7$ & $51.7 \pm 1.2$ & $21.1 \pm 0.4$ \\
\hline
\end{tabular}

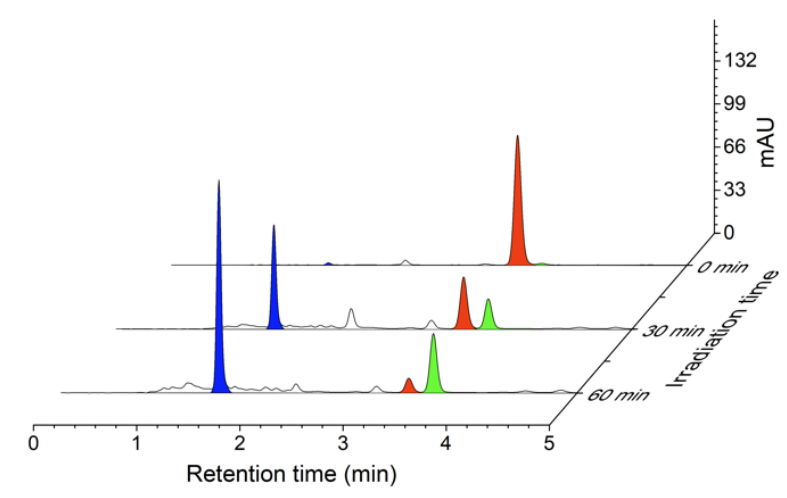

Figure 2. HPLC chromatograms registered at $280 \mathrm{~nm}$ for an oxy gen-containing MeCN: $\mathrm{H}_{2} \mathrm{O}(60: 40, v: v)$ solution of $2\left(2 \times 10^{-4} \mathrm{M}\right)$, upon irradiation at different times at $254 \mathrm{~nm}$.

The obtained results are in accordance $w$ ith the fact that formal incorporation of an oxygen atom to dyad $\mathbf{2}$ is required to release $\mathrm{CBP}$ and $\mathrm{OB}$ (Figure $1 \mathrm{~A}$ ).

To experimentally settle whether the oxygen comes from $\mathrm{H}_{2} \mathrm{O}$ and if so $w$ here it is finally incorporated, photodeprotection $w$ as carried out using $\mathrm{MeCN}: \mathrm{H}_{2}{ }^{18} \mathrm{O}$ as solvent. In this context, an oxygencontaining solution of 2 in either $\mathrm{MeCN} / \mathrm{H}_{2} \mathrm{O}$ or $\mathrm{MeCN} / \mathrm{H}_{2}{ }^{18} \mathrm{O}$ was exposed to $254 \mathrm{~nm}$ light, and the reaction mixture was analyzed by UPLC-HRMS. When $\mathrm{H}_{2} \mathrm{O}$ w as used, mass spectra of the CBP and $\mathrm{OB}$ peaks were coincident $w$ ith the expected natural isotopic pattern, with $\mathrm{m} / \mathrm{z}$ values of 227.0714 and 229.0864 as $\left[\mathrm{M}+\mathrm{H}^{+}\right]$, respectively. Conversely, for the reaction in $\mathrm{H}_{2}{ }^{18} \mathrm{O}$ a CBP peak at $\mathrm{m} / \mathrm{z} 229.0743$ increased and its exact mass corresponded to that of ${ }^{18} \mathrm{O}$ labeled CBP. By contrast, no significant changes were observed for $\mathrm{OB}$ (see Figure S4). Thus, comparison of the MS spectra for the CBP peak show ed that ratio between the intensity of the ions at $\mathrm{m} / \mathrm{z} 229.0743$ and $227.0706 \mathrm{w}$ as higher in the presence than in the absence of $\mathrm{H}_{2}{ }^{18} \mathrm{O}(1 / 3 \mathrm{vs} 1 / 33$, respectively). Moreover, no changes in the isotopic pattern were observed for CBP in $\mathrm{H}_{2}{ }^{18} \mathrm{O}$ solution left in the dark for hours (see Figure S4).

Altogether, these results demonstrate that at least part of the oxygen of CBP arises from water present in the solvent, and supports that in aerobic atmosphere the yield of CBP formation is enhanced in aqueous acetonitrile. Nonetheless, the reaction still takes place under aerobic anhydrous conditions, albeit to a lesser extent, show ing that atmospheric oxygen is also capable to trigger the process. Consequently, the low est efficiency is observed for oxygen-free anhydrous acetonitrile.

In order to explain the obtained results and to get insights into the mechanistic details of the photoprocess, laser flash photolysis (LFP) experiments were performed at $266 \mathrm{~nm}$. The transient absorption spectrum obtained for $\mathrm{N}_{2}$-bubbled aqueous solutions of 2 is show $n$ in Figure 3 . It exhibits a maximum at $350 \mathrm{~nm}$ together with a shapeless band growing until $700 \mathrm{~nm}$ characteristic of hydrated electron $\left(\mathrm{e}_{\mathrm{aq}}^{-}\right)$, which was quenched under $\mathrm{N}_{2} \mathrm{O}$ atmosphere (Figure 3, top). The linear variation of the hydrated electron absorbance at $680 \mathrm{~nm}$ as a function of the laser intensity reflected a monophotonic process (Figure 3, bottom). Furthermore, the log-log representation fitted linearly $w$ ith a slope of 1.2 (Figure S5, top) confirming the one-photon nature of the ionization process, which could thus occur under steady-state photolysis. Consistently, LFP studies carried out using $(2,4-$ dimethoxyphenyl)acetic acid (DMFA) as a model of the dialkoxyaryl group of 2 also gave rise to $e^{-}$aq (see Figure S5, right). Interestingly, the 4-carboxyaryl moiety can act as a good electron acceptor and thus be reduced during the process either through an intramolecular electron transfer process or through trapping of hydrated electron.
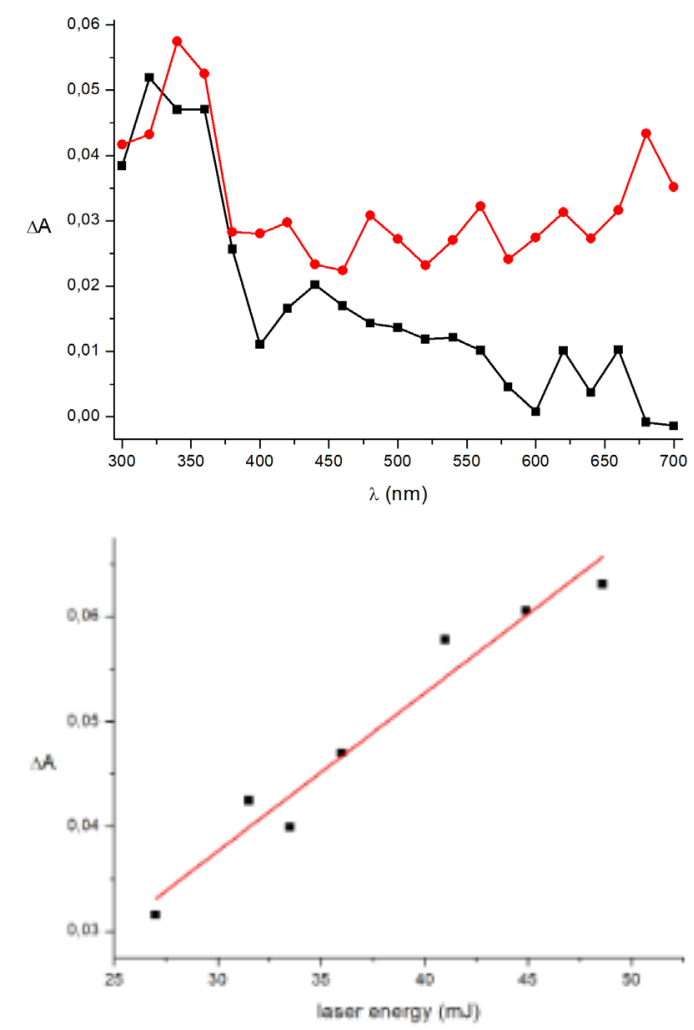

Figure 3. Top: transient absorption spectra of 2 in $\mathrm{H}_{2} \mathrm{O}$ under $\mathrm{N}_{2}$ (red line) or $\mathrm{N}_{2} \mathrm{O}$ (black line) $0.04 \mu$ s after the $266 \mathrm{~nm}$ laser pulse (laser energy: $33 \mathrm{~mJ}$ ). Bottom: laser energy dependence of the transient absorption intensity at $680 \mathrm{~nm}$ of the $\mathrm{N}_{2}$ solution. 


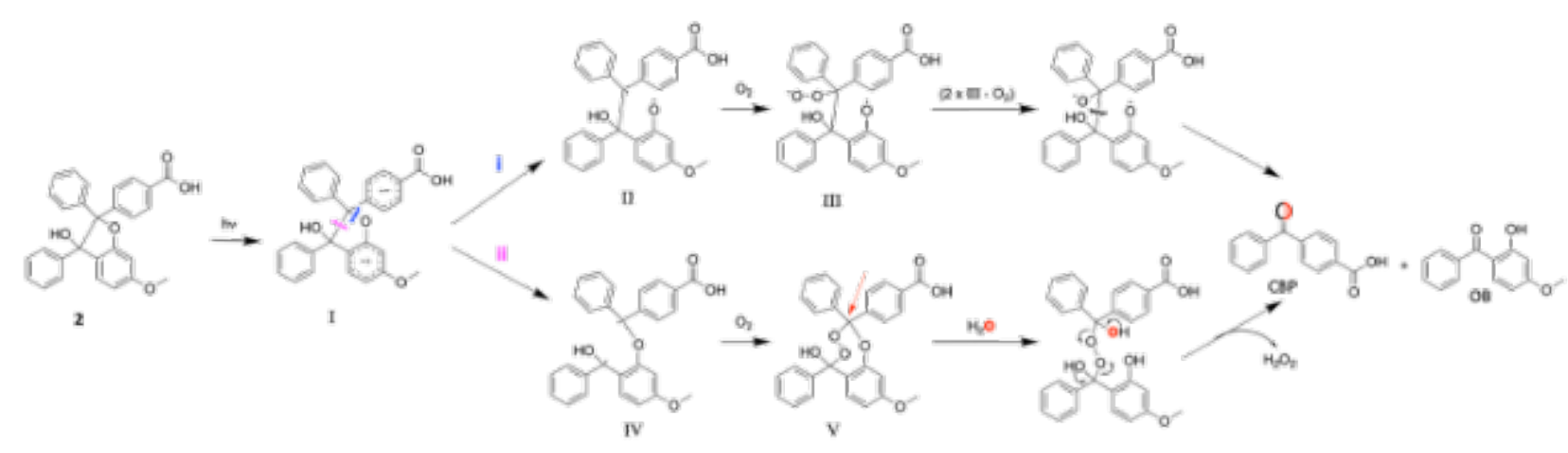

Scheme 2. Photorelease mechanism from photocage 2.

Actually, comparison of the kinetic traces of hydrated electron at $680 \mathrm{~nm}$ revealed a faster decay for 2 (Figure S5, $\tau \sim 270 \mathrm{~ns}$ ) than for DMFA (Figure S5, $\tau \sim 400 \mathrm{~ns}$ ), which is in agreement with electron trapping by the 4-carboxyaryl moiety of 2 .

On the basis of these data, a possible mechanism is outlined in Scheme 2. The photorelease process might be triggered by the photoinduced formation of biradical zwitterion I (Scheme 2). This intermediate can evolve through two different pathways depending on the mesolytic cleavage of the benzylic $\mathrm{C}-\mathrm{O}$ bond (route $i$ ) or $\mathrm{C}-\mathrm{C}$ bond (route $i$ ). In the former case, the obtained biradical II is trapped by $\mathrm{O}_{2}$ leading to III, $\mathrm{w}$ hich after dimerization and subsequent fragmentation yields the desired $\mathrm{CBP}$ and $\mathrm{OB}$. The $\mathrm{C}-\mathrm{C}$ cleavage, route $i$, gives rise to biradical IV that reacts with $\mathrm{O}_{2}$ to form the cyclic endoperoxide intermediate $\mathbf{V}$. In the presence of water, it hydrolyzes to yield, after loss of $\mathrm{H}_{2} \mathrm{O}_{2}, \mathrm{CBP}$ and $\mathrm{OB}$. In this context, incorporation of ${ }^{18} \mathrm{O}$ to $\mathrm{CBP}$ demonstrates that $w$ ater attacks at the benzylic position of the carboxyaryl moiety, which is actually the most electrophilic carbon.

\section{Conclusion}

In summary, the concept of sunscreen-based photocages for carbonyl compounds has been proven in the present work, using compounds 1 and 2, which serve as precursors of the target aromatic ketone along with its UV-filter shield. Further work is in progress to optimize the yields of the uncaging processes and to explore the scope of this approach with differently substituted ketones, such as acetophenone derivatives, and aldehydes.

\section{Experimental Section}

Synthesis.

Methyl 4-benzoylbenzoate (3). Concentrated sulfuric acid (0.025 $\mathrm{mL}, 0.44 \mathrm{mmol}$ ) was added to a solution of 4-benzoylbenzoic acid $(0.5 \mathrm{~g}, 2.2 \mathrm{mmol})$ in anhydrous $\mathrm{MeOH}(15 \mathrm{~mL})$. The solution was stirred at $75^{\circ} \mathrm{C}$ for $17 \mathrm{~h}$ and then cooled to room temperature. The solvent $w$ as removed under reduced pressure. The crude product $w$ as redissolved in dichloromethane and $w$ ashed $w$ ith saturated sodium bicarbonate. Finally, the organic phase was dried with anhydrous magnesium sulfate, filtered, and the filtrate was concentrated in vacuo. The pure product $3 \mathrm{w}$ as obtained $\mathrm{w}$ ithout further purification. Yield: $0.421 \mathrm{~g}(77 \%) .{ }^{1} \mathrm{H}$ NMR $(300 \mathrm{MHz}$,
$\left.\mathrm{CDCl}_{3}\right): \delta(\mathrm{ppm}) 8.15(\mathrm{~d}, J=8.6 \mathrm{~Hz}, 2 \mathrm{H}), 7.82(\mathrm{~m}, 4 \mathrm{H}), 7.68-7.57$ (m, 1H), $7.55-7.42(\mathrm{~m}, 2 \mathrm{H}), 3.97(\mathrm{~s}, 3 \mathrm{H})$. HRMS (ESI-TOF) $\mathrm{m} / \mathrm{z}$ $[\mathrm{M}+\mathrm{H}]^{+}$calculated for $\mathrm{C}_{15} \mathrm{H}_{13} \mathrm{O}_{3}$ : 241.0865; found: 241.0859 .

Methyl 4-[hydroxy(phenyl)methyl]benzoate (4). Compound 3 $(0.328 \mathrm{~g}, 1.36 \mathrm{mmol})$ was dissolved in a mixture of anhydrous methanol $(5 \mathrm{~mL})$ and anhydrous dichloromethane $(2 \mathrm{~mL})$. The resulting solution was cooled to $0^{\circ} \mathrm{C}$, and then $\mathrm{NaBH}_{4}(0.072 \mathrm{~g}$, $1.9 \mathrm{mmol}$ ) was added portionw ise during $2 \mathrm{~h}$. Subsequently, the solution was allow ed reaching room temperature, and stirred for $3 \mathrm{~h}$. To quench the excess of $\mathrm{NaBH}_{4}$, the solution was cooled in an ice bath, and then water $(5 \mathrm{~mL})$ was added. The resulting mixture $w$ as stirred for $30 \mathrm{~min}$. The mixture of solvents were removed under reduced pressure, then the afforded crude was redissolved with dichloromethane $(20 \mathrm{~mL})$ and washed with water. Finally, the combined organic extracts were dried with $\mathrm{MgSO}_{4}$, filtered, and the solvent was removed under reduced pressure. The pure product 4 was obtained without further purification. Yield: $0.282 \mathrm{~g}(85 \%) .{ }^{1} \mathrm{H}$ NMR $\left(300 \mathrm{MHz}, \mathrm{CDCl}_{3}\right): \delta$ (ppm) $7.91(\mathrm{~d}, J=8.4 \mathrm{~Hz}, 2 \mathrm{H}), 7.38(\mathrm{~d}, J=8.1 \mathrm{~Hz}, 2 \mathrm{H}), 7.33-$ $7.11(\mathrm{~m}, 5 \mathrm{H}), 5.79(\mathrm{~d}, J=3.3 \mathrm{~Hz}, 1 \mathrm{H}), 3.81(\mathrm{~s}, 3 \mathrm{H}), 2.40(\mathrm{~d}, J=$ $3.3 \mathrm{~Hz}, 1 \mathrm{H}$ ). HRMS (ESI-TOF) $\mathrm{m} / \mathrm{z}[\mathrm{M}+\mathrm{H}]^{+}$calculated for $\mathrm{C}_{15} \mathrm{H}_{15} \mathrm{O}_{3}$ : 243.1021; found: 243.1021 .

\section{Methyl}

4-[(2-benzoyl-5methoxyphenoxy)(phenyl)methyl]benzoate (5). To a solution of compound $4(0.249 \mathrm{~g}, 1.03 \mathrm{mmol})$ and triphenylphosphine $\left(\mathrm{PPh}_{3}\right)$ $(0.324 \mathrm{~g}, 1.23 \mathrm{mmol})$ in anhydrous dioxane $(5.5 \mathrm{~mL})$ was added oxybenzone (0.353 g, $1.55 \mathrm{mmol})$ and diisopropyl azodicarboxylate (DIAD) $(0.350 \mathrm{~mL}, 2 \mathrm{mmol})$. The solution was stirred at room temperature for $4 \mathrm{~h}$. The crude reaction mixture w as concentrated under reduced pressure and purified by column chromatography (cyclohexane/ethyl acetate, $4: 1$; silica gel) to give the pure product 5 . Yield: $0.340 \mathrm{~g}(73 \%) .{ }^{1} \mathrm{H} \mathrm{NMR}(300 \mathrm{MHz}$, $\left.\mathrm{CDCl}_{3}\right): \delta(\mathrm{ppm}) 7.95-7.80(\mathrm{~m}, 4 \mathrm{H}), 7.60-7.41(\mathrm{~m}, 4 \mathrm{H}), 7.20$ $(\mathrm{m}, 7 \mathrm{H}), 6.55(\mathrm{dd}, J=8.5,2.0 \mathrm{~Hz}, 1 \mathrm{H}), 6.48(\mathrm{~d}, J=2.0 \mathrm{~Hz}, 1 \mathrm{H})$, $6.19(\mathrm{~s}, 1 \mathrm{H}), 3.86(\mathrm{~s}, 3 \mathrm{H}), 3.71(\mathrm{~s}, 3 \mathrm{H}) .{ }^{13} \mathrm{C} \mathrm{NMR}\left(75 \mathrm{MHz}, \mathrm{CDCl}_{3}\right)$ : $\delta$ (ppm) 195.9, 166.5, 163.1, 157.2, 145.9, 140.2, 139.5, 132.3, $132.3,129.8,129.5,129.2,128.6,128.1,127.9,126.1,125.9$, 122.4 , 105.6, 101.4, 81.8, 55.3, 51.9. HRMS (ESI-TOF) $\mathrm{m} / \mathrm{z}$ $[\mathrm{M}+\mathrm{H}]^{+}$calculated for $\mathrm{C}_{29} \mathrm{H}_{25} \mathrm{O}_{5}$ : 453.1702; found: 453.1713 . 
4-(3-hydroxy-6-methoxy-2,3-diphenyl-2,3-dihydrobenzofuran-2yl)benzoic acid (1). Compound 5 (0.191 g, $0.42 \mathrm{mmol}$ ) was dissolved in a mixture of $1 \mathrm{M}$ aq. $\mathrm{NaOH}(2 \mathrm{~mL})$ and THF (2 mL). The resulting solution $w$ as stirred for $22 \mathrm{~h}$ at room temperature. The mixture was acidified to $\mathrm{pH} 1$ using $1 \mathrm{M}$ aq. $\mathrm{HCl}$, then the resulting mixture $w$ as extracted $w$ ith dichloromethane $(3 \times 10 \mathrm{~mL})$, dried over anhydrous $\mathrm{MgSO}_{4}$, and rotary evaporated to afford compound $1(0.127 \mathrm{~g})$ in a $69 \%$ yield. ${ }^{1} \mathrm{H}$ NMR $\left(300 \mathrm{MHz}, \mathrm{CDCl}_{3}\right)$ : $\delta$ (ppm) 7.88 (d, J = 8.1 Hz, 2H), 7.80 (d, J=7.2 Hz, 2H), $7.47(\mathrm{~m}$, $4 \mathrm{H}), 7.25-6.98(\mathrm{~m}, 7 \mathrm{H}), 6.54(\mathrm{dd}, J=8.7,1.8 \mathrm{~Hz}, 1 \mathrm{H}), 6.41$ (d, $J$ $=1.8 \mathrm{~Hz}, 1 \mathrm{H}), 6.12(\mathrm{~s}, 1 \mathrm{H}), 3.73(\mathrm{~s}, 3 \mathrm{H}) \cdot{ }^{13} \mathrm{C} \mathrm{NMR}(75 \mathrm{MHz}$, $\left.\mathrm{CDCl}_{3}\right): \delta(\mathrm{ppm}) 196.29,163.29,157.39,146.57,140.29,139.61$, $132.55,132.51,130.52,129.67,129.27,128.86,128.27,128.09$, $126.33,126.09,122.68,105.85,101.60,82.15,55.54$. HRMS (ESI-TOF) $\mathrm{m} / \mathrm{z}[\mathrm{M}+\mathrm{H}]^{+}$calculated for $\mathrm{C}_{28} \mathrm{H}_{23} \mathrm{O}_{5}$ : 439.1545; found: 439.1550. Molar absorption coefficients in $\mathrm{MeCN}: \mathrm{H}_{2} \mathrm{O}$ (60:40, $\mathrm{v}: \mathrm{v}): \log \varepsilon=3.9(280 \mathrm{~nm}), 3.7(310 \mathrm{~nm})$.

Methyl 4-(3-hydroxy-6-methoxy-2,3-diphenyl-2, 3dihydrobenzofuran-2-yl)benzoate (6). An oxygen-free solution of compound $5(0.170 \mathrm{~g}, 0.376 \mathrm{mmol})$ in $211 \mathrm{~mL}$ cyclohexane and 9 $\mathrm{mL}$ dichloromethane was irradiated for 90 min using a Luzchem photoreactor (model LZC-4V) with 8 lamps $w$ ith a maximum output at $355 \mathrm{~nm}$. Then, the solvent $w$ as removed under vacuum. Purification was performed by column chromatography (cyclohexane/ethyl acetate, 6:1; silica gel). Product 6 was obtained by resolution of the diastereoisomeric mixture $(0.058 \mathrm{~g})$ in a $34 \%$ yield. ${ }^{1} \mathrm{H}$ NMR $\left(300 \mathrm{MHz}, \mathrm{CDCl}_{3}\right): \delta$ (ppm) $8.07-7.96$ $(\mathrm{d}, J=8.7 \mathrm{~Hz}, 2 \mathrm{H}), 7.95-7.83(\mathrm{~d}, J=8.7 \mathrm{~Hz}, 2 \mathrm{H}), 7.15(\mathrm{~m}, 5 \mathrm{H})$, $7.08-6.90(\mathrm{~m}, 5 \mathrm{H}), 6.82(\mathrm{~m}, 2 \mathrm{H}), 6.48(\mathrm{dd}, J=8.3,2.2 \mathrm{~Hz}, 1 \mathrm{H})$, $3.88(\mathrm{~s}, 3 \mathrm{H}), 3.86(\mathrm{~s}, 3 \mathrm{H}) \cdot{ }^{13} \mathrm{C} \mathrm{NMR}\left(75 \mathrm{MHz} \mathrm{CDCl}_{3}\right): \delta$ (ppm) $166.9,162.6,160.2,146.0,140.9,140.8,129.2,129.1,128.1$, $127.8,127.4,127.4,127.3,127.2,127.0,126.5,125.9,108.3$, 99.5, 96.4, 87.8, 55.8, 52.2. HRMS (ESI-TOF) $\mathrm{m} / \mathrm{z}[\mathrm{M}-\mathrm{OH}]^{+}$ calculated for $\mathrm{C}_{29} \mathrm{H}_{23} \mathrm{O}_{4}$ : 435.1596; found: 435.1595 . Based on the spectroscopic data, this compound has the two phenyl groups in cis arrangement.

4-(3-hydroxy-6-methoxy-2,3-diphenyl-2,3-dihydrobenzofuran-2yl)benzoic acid (2). Compound 6 (0.057 g, $0.13 \mathrm{mmol})$ was dissolved in a mixture of $1 \mathrm{M}$ aq. $\mathrm{NaOH}(0.56 \mathrm{~mL})$ and THF $(0.56$ $\mathrm{mL})$. The resulting solution $w$ as stirred for $22 \mathrm{~h}$ at room temperature. The mixture was acidified to $\mathrm{pH} 1$ using $1 \mathrm{M}$ aq. $\mathrm{HCl}$, then the resulting mixture $w$ as extracted $w$ ith dichloromethane (3 x $10 \mathrm{~mL}$ ), dried over anhydrous $\mathrm{MgSO}_{4}$, and rotary evaporated to afford compound $2(0.013 \mathrm{~g})$ in a $23 \%$ yield. ${ }^{1} \mathrm{H}$ NMR $(300 \mathrm{MHz}$, MeOD): $\delta(p p m) 7.97(\mathrm{~d}, J=8.5 \mathrm{~Hz}, 2 \mathrm{H}), 7.90$ (d, $J=8.5 \mathrm{~Hz}, 2 \mathrm{H})$, $7.21-6.88(\mathrm{~m}, 10 \mathrm{H}), 6.84(\mathrm{~d}, J=2.2 \mathrm{~Hz}, 1 \mathrm{H}), 6.77(\mathrm{~d}, J=8.3 \mathrm{~Hz}$, $1 \mathrm{H}), 6.50(\mathrm{dd}, J=8.3,2.2 \mathrm{~Hz}, 1 \mathrm{H}), 3.86(\mathrm{~s}, 3 \mathrm{H}) .{ }^{13} \mathrm{C} \mathrm{NMR}(75$ $\mathrm{MHz}, \mathrm{MeOD}): \delta$ (ppm) 162.3, 160.1, 146.4, 141.9, 141.6, 128.1, 127.8, 127.5, 126.8, 126.6, 126.5, 126.1, 125.5, 107.4, 99.1, 95.4, 86.9, 54.6. HRMS (ESI-TOF) $\mathrm{m} / \mathrm{z}\left[\mathrm{M}-\mathrm{OH}^{+}\right.$calculated for $\mathrm{C}_{28} \mathrm{H}_{21} \mathrm{O}_{4}$ : 421.1440; found: 421.1439. Molar absorption coefficient in $\mathrm{MeCN}: \mathrm{H}_{2} \mathrm{O}$ (60:40, v:v): $\log \varepsilon=3.8(283 \mathrm{~nm})$.
UV-Vis. The absorption spectra were registered with a simple beam spectrophotometer (Cary 50 ) using a quartz cell of $1 \mathrm{~cm}$ optical path.

Steady-State Photolysis. All irradiations were carried out at room temperature using $3 \mathrm{~mL}$ quartz cuvettes of $1 \mathrm{~cm}$ optical path. Photolysis of compound $\mathbf{2}$ were run using a Luzchem photoreactor (model LZC-4V, 8W) with one low pressure Hg lamp with an output at $254 \mathrm{~nm}$. Irradiation of compound $1 \mathrm{w}$ as carried out in a mixture of $\mathrm{MeCN}: \mathrm{H}_{2} \mathrm{O}$ (60:40, v:v) under oxygen-free conditions using a simulated solar light (SSL) obtained from a Xenon arc lamp solar simulator (Thermo Oriel 91192-1000) equipped with a AM 1.5 filter Global to better match the solar emission spectra, its output was of $86 \mathrm{~mW} / \mathrm{cm}^{2}$. Solutions of compound $2\left(2 \times 10^{-4} \mathrm{M}\right)$ were prepared in anhydrous acetonitrile or in $\mathrm{MeCN}: \mathrm{H}_{2} \mathrm{O}$ (60:40, v:v) under nitrogen or air, and irradiations were run in quartz cells of $1 \mathrm{~cm}$ optical path. The oxygen-free and anhydrous solution of $\mathbf{2} \mathrm{w}$ as prepared in a dry box. The course of the photoreaction $w$ as followed by $U V-V$ is absorption spectrometry and HPLC.

HPLC. All irradiation mixtures were analyzed by a 1100 Series Agilent HPLC equipped $w$ ith a diode array detector (DAD), for all chromatograms the detection wavelength was $280 \mathrm{~nm}$. Irradiations were analyzed using a Zorbax Eclipse Plus C18 (4.6 x $100 \mathrm{~mm}, 3.5$ Micron) column, and the chromatographic conditions were an isocratic mixture of $w$ ater at $\mathrm{pH} 3(35 \%)$ and acetonitrile $(65 \%)$ at a flow rate of $1 \mathrm{~mL} / \mathrm{min}$. The injection volume was of $10 \mu \mathrm{L}$. The areas of the peaks were integrated by using the "OpenLab CDS ChemStation Edition" software supplied by Agilent. The percent yields were determined from calibration curves of pure samples of $\mathrm{OB}, \mathrm{CBP}, \mathbf{1}$ and $\mathbf{2}$.

The quantum yield of the photoreaction was established using $\mathrm{N}$ methyldiphenylamine in $\mathrm{MeCN}$ as actinometer ( $\phi_{\text {ref }}=0.45$ ) irradiating at $254 \mathrm{~nm}^{[36,37]}$

UPLC-HRMS. Exact mass values were determined by using a QTof spectrometer coupled with a liquid chromatography system. The separation was carried out by UPLC on a Zorbax Eclipse Plus C18 column (4.6 x $100 \mathrm{~mm}, 3.5$-micron). The mobile phase was a gradient prepared from $0.1 \%$ aqueous formic acid solution (component $\mathrm{A}$ ) and $0.1 \%$ formic acid in acetonitrile (component $B)$. The column was equilibrated with $A: B(80: 20 ; v: v)$ as mobile phase at a flow rate of $0.5 \mathrm{~mL} \mathrm{~min}{ }^{-1}$. The amount of component $A$ was maintained at this composition for $3 \mathrm{~min}$, then decreased from 80 to $0 \%$ in $7 \mathrm{~min}$, kept at $0 \%$ for $5 \mathrm{~min}$, restored to the initial composition in $2 \mathrm{~min}$, and finally maintained at this composition for $3 \mathrm{~min}$. The injection volume was of $5 \mathrm{~mL}$. The ESI source was operated in positive ionization mode with the capillary voltage at $3 \mathrm{kV}$. The temperature of the source and desolvation was set at 80 and $400{ }^{\circ} \mathrm{C}$, respectively. The cone and desolvation gas flows were 20 and $800 \mathrm{~L} \mathrm{~h}^{-1}$, respectively. All data were collected in centroid mode. Leucine-enkephalin $w$ as used as the lock mass generating an $\left[\mathrm{M}+\mathrm{H}^{+}\right.$ion $(\mathrm{m} / \mathrm{z} 556.2771)$ at a concentration of $250 \mathrm{pg} / \mathrm{mL}$ and flow rate of $50 \mu \mathrm{L} / \mathrm{min}$ to ensure accuracy during 
the MS analysis. MS/MS spectra of compound 2 were measured for parent ion at $\mathrm{m} / \mathrm{z} 421.14$, using a $\mathrm{V}_{\text {coll }}$ of $30 \mathrm{~V}$.

Laser Flash Photolysis. Laser flash photolysis experiments were performed exciting at $266 \mathrm{~nm}$, using the $4^{\text {th }}$ harmonic of a pulsed Nd:YAG laser (L52137V LOTIS TII) with a pulse duration of 6-8 ns. The full system consists in a pulsed laser, a Xenon lamp (Lo 255 Oriel), a monochromator (Oriel 77200), a photomultiplier (Oriel 70705) and an oscilloscope (TDS-640A Tektronic). The output signal from the oscilloscope was transferred to a personal computer. All experiments were performed in a quartz cell of $1 \mathrm{~cm}$ optical path length. Compound $\mathbf{2}$ was prepared in water such as its $266 \mathrm{~nm}$ absorption was of ca. 0.3. Before running the experiment, solutions were flushed w ith $\mathrm{N}_{2}$ or $\mathrm{N}_{2} \mathrm{O}$ for 15 min. A laser intensity ranging from 27 to $49 \mathrm{~mJ}$ per pulse was used.

\section{Acknowledgements}

This work was supported by the Spanish Government (project PGC2018-096684-B-100) and the Universitat Politècnica de València (FPI grant to M.L.-R.). Carmen Clemente Martínez is acknow ledged for her technical help during the UPLC-HRMS experiments.

Keyw ords: Laser spectroscopy • Photocage - Photochemistry • Photoprotection • Solar filter

[1] J. M. Silva, E. Silva, R. L. Reis, J. Control. Release 2019, 298, 154-176.

[2] M. Klausen, V. Dubois, J.-B. Verlhac, M. BlanchardDesce, ChemPlusChem 2019, 84, 589-598.

[3] C. Brieke, F. Rohrbach, A. Gottschalk, G. Mayer, A. Heckel, Angew. Chem. Int. Ed. 2012, 51, 8446-8476.

[4] T. Šolomek, J. Wirz, P. Klán, Acc. Chem. Res. 2015, 48, 3064-3072.

[5] C. G. Bochet, A. Blanc, in CRC Handbook of Organic Photochemistry and Photobiology (3rd Edition) (Eds.: A. Griesbeck, M. Oelgemoller, F. Ghetti), Wiley-VCH Verlag $\mathrm{GmbH} \&$ Co. KGaA, 2012, pp. 417-447,

[6] P. Klán, T. Šolomek, C. G. Bochet, A. Blanc, R. Givens, M. Rubina, V. Popik, A. Kostikov, J. Wirz, Chem. Rev. 2013, 113, 119-191.

[7] A. Herrmann, Angew. Chem. Int. Ed. 2007, 46, 58365863.

[8] P. Wang, J. Photochem. Photobiol. A 2017, 335, 300-310.

[9] A. G. Griesbeck, B. Porschen, C. Kropf, A. Landes, O. Hinze, U. Huchel, T. Gerke, Synthesis 2017, 49, 539-553.

[10] A. Herrmann, Photochem. Photobiol. Sci. 2012, 11, 446459.

[11] D. E. Falvey, C. Sundararajan, Photochem. Photobiol. Sci. 2004, 3, 831-838.

[12] J. Hebert, D. Gravel, Can. J. Chem. 1974, 52, 187-189.

[13] D. Gravel, J. Hebert, D. Thoraval, Can. J. Chem. 1983, 61 400-410.

[14] P. Wang, A. Hu, Y. Wang, Org. Lett. 2007, 9, 2831-2833.

[15] W. Pengfei, H. Huayou, W. Yun, Org. Lett. 2007, 9, 15331535.

[16] H. Yang, X. Zhang, L. Zhou, P. Wang, J. Org. Chem. 2011, 76, 2040-2048.

[17] A.P. Kostikov, N. Malashikhina, V. V. Popik, J. Org. Chem. 2009, 74, 1802-1804.

[18] A. Blanc, C. G. Bochet, J. Org. Chem. 2003, 68, 11381141.

[19] J. y. Yu, W. J. Tang, H. B. Wang, Q. H. Song, J. Photochem. Photobiol. A. 2007, 185, 101-105.
[20] M. Lu, O. D. Fedoryak, B. R. Moister, T. M. Dore, Org. Lett. 2003, 5, 2119-2122.

[21] B. Levrand, A. Herrmann, Flavour Fragr. J. 2006, 21, 400409.

[22] B. Levrand, A. Herrmann, Chimia 2007, 61, 661-664.

[23] A. G. Griesbeck, O. Hinze, H. Görner, U. Huchel, C. Kropf, U. Sundermeier, T. Gerke, Photochem. Photobiol. Sci. 2012, 11, 587-592.

[24] R. G. Brinson, P. B. Jones, Org. Lett. 2004, 6, 3767-3770.

[25] R. G. Brinson, S. C. Hubbard, D. R. Zuidema, P. B. Jones, J. Photochem. Photobiol. A 2005, 175, 118-128.

[26] R. L. Blankespoor, T. DeVries, E. Hansen, J. M. Kallemeyn, A. M. Klooster, J. A. Mulder, R. P. Smart, D. A Vander Griend, J. Org. Chem. 2002, 67, 2677-2681.

[27] W. A. McHale, A. G. Kutateladze, J. Org. Chem. 1998, 63, 9924-9931.

[28] Z. Li, Y. Wan, A. G. Kutateladze, Langmuir 2003, 19, 6381-6391.

[29] J. R. R. Majjigapu, A. N. Kurchan, R. Kottani, T. P. Gustafson, A. G. Kutateladze, J. Am. Chem. Soc. 2005, 127, 12458-12459.

[30] R. Kottani, R. A. Valiulin, A. G. Kutateladze, Proc. Natl. Acad. Sci. USA 2006, 103, 13917-13921.

[31] K. Majigapu, J. R. R. Maijigapu, A. G. Kutateladze, Angew. Chem. Int. Ed. 2007, 46, 6137-6140.

[32] P. Vath, D. E. Falvey, L. A. Barnhurst, A. G. Kutateladze, J. Org. Chem. 2001, 66, 2887-2890.

[33] P. Štacko, P. Šebej, A. T. Veetil, P. Klán, Org. Lett. 2012, 14, 4918-4921.

[34] I. Aparici-Espert, M. C. Cuquerella, C. Paris, V. LhiaubetVallet, M. A. Miranda, Chem. Commun. 2016, 52, 1421514218.

[35] I. Aparici-Espert, M. A. Miranda, V. Lhiaubet-Vallet, Molecules 2018, 23,673.

[36] M. Marin, V. Lhiaubet-Vallet, M. A. Miranda, Org. Lett. 2012, 14, 1788-1791.

[37] H. Gorner, J. Phys. Chem. A 2008, 112, 1245-1250. 
